\title{
Assessment of the effects of metformin and glibenclamide on the concentration of selected trace elements in type 2 diabetic patients
}

\author{
Jehan A. Mohammad', Ammar A.Y. Almulathanon ${ }^{2}$, Fatimah Haitham Fathi ${ }^{3}$ \\ 1 Department of Pharmacognosy and Medicinal Plants, College of Pharmacy, University of Mosul \\ 2 Department of Pharmacology and Toxicology, College of Pharmacy, University of Mosul \\ 3 Department of Clinical Laboratory Sciences, College of Pharmacy, University of Mosul \\ Corresponding author: Ammar A. Y. Almulathanon (ammara@uomosul.edu.iq)
}

Received 23 July 2021 • Accepted 23 October 2021 • Published 10 November 2021

Citation: Mohammad JA, Almulathanon AAY, Fathi FH (2021) Assessment of the effects of metformin and glibenclamide on the concentration of selected trace elements in type 2 diabetic patients. Pharmacia 68(4): 845-849. https://doi.org/10.3897/pharmacia.68.e72080

\begin{abstract}
Metformin and glibenclamide may have beneficial effects on the levels of trace elements in diabetic patients. The aim of the current study was to assess the effects of metformin and glibenclamide on the concentrations of copper $(\mathrm{Cu})$, zinc $(\mathrm{Zn})$ and magnesium $(\mathrm{Mg})$ in patients with type 2 diabetes mellitus. The metformin-treated patients showed significantly lower serum Cu levels compared with the untreated and glibenclamide groups. In addition, treatment with metformin was associated with a significant increase in serum concentrations of $\mathrm{Zn}$ compared to the newly diagnosed patients, whereas it did not show a noticeable alteration in the serum level of $\mathrm{Mg}$. In contrast, the glibenclamide treated group revealed significantly higher $\mathrm{Zn}$ and $\mathrm{Mg}$ levels compared with the newly diagnosed group, while the serum level of $\mathrm{Cu}$ was not significantly modified. In conclusion, treatment with metformin led to a reduction in serum $\mathrm{Cu}$ and an increase in serum $\mathrm{Zn}$ concentrations, whereas glibenclamide treatment displayed enhancement in serum $\mathrm{Zn}$ and $\mathrm{Mg}$ levels.
\end{abstract}

\section{Keywords}

Copper, Glibenclamide, Magnesium, Metformin, Zinc

\section{Introduction}

Trace elements are divalent cations that play essential roles in the human body. These cations, including copper $(\mathrm{Cu})$, zinc $(\mathrm{Zn})$ and magnesium $(\mathrm{Mg})$, are necessary for different cellular functions and the alterations in their concentrations can contribute to the development of many diseases, such as T2DM (Dosa et al., 2011, Viktorinova et al., 2009). $\mathrm{Cu}$ and $\mathrm{Zn}$ have a crucial role in the mechanisms of oxidation-reduction reactions. $\mathrm{Cu}$ has both prooxidant and antioxidant effects through the generation of free radicals and catalyzation of the superoxide dismutase enzyme, which protects cells from superoxide radicals, respectively. In contrast, $\mathrm{Zn}$ has only an antioxidant effect by preventing reactive oxygen species from causing damage to proteins and enzymes (DiSilvestro, 2000). So, an oxidant/ antioxidant imbalance can result from a disturbance in the level of these elements, which in turn induces diabetes and its complications (Soinio et al., 2007). In addition, low Zn levels can negatively affect the production and secretion of 
insulin from the islet cells of the pancreas (Quraishi et al., 2005). $\mathrm{Mg}$ is another important trace element that has a vital role in glucose homeostasis. It has been found that its deficiency can contribute to decreased insulin sensitivity and secretion (Huerta et al., 2005).

Although numerous studies have been carried out to determine the serum levels of trace elements in type $2 \mathrm{di}$ abetic patients receiving metformin, contradictory results have been obtained (Chakraborty et al., 2011, Peters et al., 2013). Moreover, little known data is available on the effect of glibenclamide on the concentrations of various divalent cations in type 2 diabetic patients. Hence, taking into consideration the aforementioned findings, the present study was performed to investigate the effects of metformin versus glibenclamide on the concentrations of some trace elements $(\mathrm{Cu}, \mathrm{Zn}$, and $\mathrm{Mg}$ ) in T2DM patients.

\section{Materials and methods Subjects}

This was a case-control retrospective study that included 64 subjects (controls and diabetics of both genders) aged between 28 and 56 years. Patients with T2DM were diagnosed and recruited at the Al-Waffaa Diabetes Management and Research Centre, Mosul, Iraq, between August-December, 2019. This study was authorised by the Committee of Research Ethics of the University of Mosul, Pharmacy College. Prior to their participation in the study, informed permission was received from all participants and the study process was carried out in line with the latest update of the Helsinki Declaration. Patient group, comprised of 48 individuals with T2DM, was categorized into three groups (16 patients each). Group B included newly diagnosed diabetic patients, group $\mathrm{C}$ included patients already treated with metformin (SioforR, Berlin Chemie) $500 \mathrm{mg}$ two times per day for a 3-12 months period, and group D included patients already receiving glibenclamide (GlibesynR, Medochemie) $2.5 \mathrm{mg}$ two times per day for the same period as group C. The control group (Group A) included healthy subjects with age matching to the patient group. Patients complaining of any systemic disease other than type 2 diabetes, pregnant and lactating mothers, alcoholics, smokers, patients taking drugs other than metformin or glibenclamide, or those receiving vitamins or minerals, and those who have undergone treatment modifications during the treatment period have not been included in the study. The body mass index (BMI) has been calculated according to the height and weight of all subjects.

\section{Sample collection}

Following an overnight fast, blood samples were drawn from all participants and collected in plain tubes. After 10 minutes of incubation in a water bath at $37^{\circ} \mathrm{C}$, samples were centrifuged at $4,000 \mathrm{x} g$ for 10 minutes to separate serum and then stored at $-20^{\circ} \mathrm{C}$ until measurement.

\section{Evaluation of serum glucose and insulin}

The concentration of fasting serum glucose (FSG) was assessed by an enzymatic colorimetric method at $505 \mathrm{~nm}$ absorbance. The level of serum insulin was determined at $450 \mathrm{~nm}$ absorbance using the enzyme linked immunosorbent assay (ELISA) technique.

\section{Estimation of serum copper, zinc, and magnesium}

An atomic absorption spectrophotometer (Shimadzu AA670 , Kyoto, Japan) was used to determine $\mathrm{Cu}, \mathrm{Zn}$, and $\mathrm{Mg}$ in serum. Prior to analysis, serum samples of $\mathrm{Cu}, \mathrm{Zn}$, and $\mathrm{Mg}$ were diluted with deionized water with a dilution factor of 1,5 and 50, respectively. Different concentrations (0.1-2.5 ppm) of $\mathrm{Cu}, \mathrm{Zn}$ and $\mathrm{Mg}$ solutions were used for system calibration. The absorbance of $\mathrm{Cu}, \mathrm{Zn}$, and $\mathrm{Mg}$ was measured at 224.8, 213.9, and $285.2 \mathrm{~nm}$, respectively.

\section{Statistical analysis}

All values were shown as mean $\pm \mathrm{SD}$. The Kruskal-Wallis test followed by the Dunn's multiple comparison test were used for multiple comparisons. $\mathrm{P}<0.05$ was considered a statistically significant difference. Statistical analyses were performed using GraphPad Prism software version 8.0 (San Diego, California, USA).

\section{Results}

Demographic characteristics of the study groups:

Age, duration of diabetes and BMI of diabetic patients and controls are shown in Table 1. Non-significant differences were found between the groups.

\section{Estimation of serum insulin and glucose concentrations}

Table 1. Demographic characteristics of diabetic patients and control subjects.

\begin{tabular}{lcccc}
\hline Parameters & Control & $\begin{array}{c}\text { Newly di- } \\
\text { agnosed }\end{array}$ & Metformin & Glibenclamide \\
\hline Age (years) & $41.9 \pm 8.43$ & $41 \pm 7.6$ & $44.1 \pm 6.3$ & $42.88 \pm 6.6$ \\
BMI $\left(\mathrm{kg} / \mathrm{m}^{2}\right)$ & $26.3 \pm 2.9$ & $26.1 \pm 0.5$ & $25.65 \pm 0.8$ & $25.64 \pm 1.1$ \\
$\begin{array}{l}\text { Duration of } \\
\text { treatment }\end{array}$ & - & - & $6.9 \pm 2.8$ & $6.8 \pm 3$ \\
(months) & & & & \\
\hline
\end{tabular}

Table (2) shows the FSG and insulin of all the participating groups. It has been found that serum glucose concentration was significantly higher in the newly diagnosed and glibenclamide treated groups compared to the control group. In contrast, the metformin treated group exhibited a comparable FSG level to that of the control group and 
significantly lower as compared to the newly diagnosed diabetics. However, the insulin level was found to be significantly lower in metformin and newly diagnosed patients compared to the control group, while the glibenclamide treated and control groups revealed comparable levels.

\section{Estimation of serum concentrations of copper, zinc, and magnesium}

Table 2. Estimation of serum glucose and insulin of participating individuals.

\begin{tabular}{lcccc}
\hline Parameters & Control & $\begin{array}{c}\text { Newly } \\
\text { diagnosed }\end{array}$ & Metformin & $\begin{array}{c}\text { Gliben- } \\
\text { clamide }\end{array}$ \\
\hline FSG $(\mathrm{mmol} / \mathrm{l})$ & $5.3 \pm 0.4$ & $11.9 \pm 1.4^{\mathrm{a}^{* * * *}}$ & $9.1 \pm 0.2^{\mathrm{b}^{* * * *}}$ & $11 \pm 0.8^{\mathrm{a}^{* * * *}}$ \\
Insulin $(\mu \mathrm{u} / \mathrm{L})$ & $10.5 \pm 1.3$ & $8.2 \pm 0.9^{\mathrm{a}^{* * * *}}$ & $8.9 \pm 0.7^{\mathrm{a}^{*}}$ & $9.5 \pm 0.4$ \\
\hline
\end{tabular}

Data is presented as mean $\pm \mathrm{SD}$. ${ }^{\text {a }}$ Comparison versus control; ${ }^{\mathrm{b}}$ Comparison versu newly diagnosed group. Statistically significant differences were evaluated by the Kruskal-Wallis and a Dunn's multiple comparisons post-hoc test $\left({ }^{*} p<0.05\right.$; $\left.{ }^{* * * *} p<0.0001\right)$

Our data showed that serum concentrations of $\mathrm{Cu}$ were significantly higher in the glibenclamide and untreated diabetic patients compared to the control group. In contrast, treatment with metformin led to a decrease in serum $\mathrm{Cu}$ level to become comparable with that of the control group and significantly lower compared with the glibenclamide treated and newly diagnosed groups (Figure 1A) As shown in Figure 1B, both glibenclamide treated and the control groups have comparable serum $\mathrm{Zn}$ concentrations, whereas metformin treated and newly diagnosed patients have significantly lower $\mathrm{Zn}$ levels as compared with the control. However, treatment with metformin and glibenclamide significantly increased serum $\mathrm{Zn}$ levels compared to the newly diagnosed group. Concerning serum $\mathrm{Mg}$, the glibenclamide and control groups showed a comparable level, whereas the metformin treated and newly diagnosed groups showed significantly lower levels compared with the control. Although glibenclamide treated patients revealed significantly higher Mg levels compared with the newly diagnosed diabetics, there were no significant differences in comparison with the metformin treated group (Figure 1C).

\section{Discussion}

While the role of glibenclamide and metformin in the treatment of diabetes has been well assessed, little evidence about their activity on trace elements in type 2 diabetic patients exists. This study aimed to investigate the effects of glibenclamide and metformin on $\mathrm{Cu}, \mathrm{Zn}$ and $\mathrm{Mg}$ levels in type 2 diabetic patients.

The findings of the current study revealed that newly diagnosed diabetic patients have much higher $\mathrm{Cu}$ levels and lower $\mathrm{Zn}$ and $\mathrm{Mg}$ levels than healthy controls. In addition, newly diagnosed diabetic patients showed higher FSG and lower insulin levels compared to the control. These results were consistent with previously reported studies, indicating
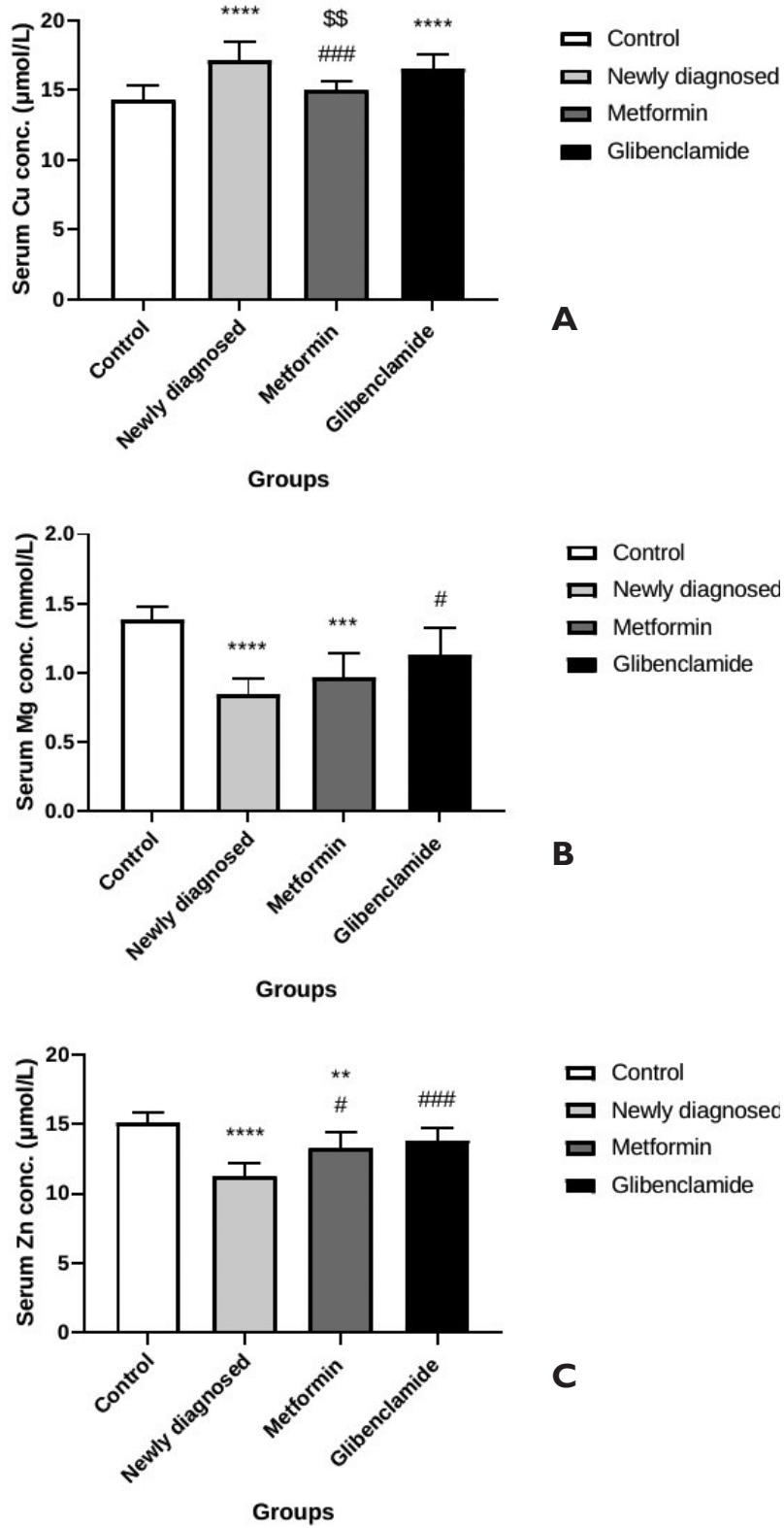

Figure 1. Effects of metformin versus glibenclamide on serum concentrations of $\mathrm{A}$ ) $\mathrm{Cu}, \mathrm{B}) \mathrm{Zn}$, and C) $\mathrm{Mg}$ in type 2 diabetic patients. ${ }^{\star}$ indicates statistically significant differences compared to the control group ( ${ }^{* *} \mathrm{p}<0.01 ;{ }^{* * *} \mathrm{p}<0.001$; ${ }^{* * *} \mathrm{p}<0.0001$ ); \# indicates statistically significant differences compared to the newly diagnosed group (\#p $<0.05 ; \# \#$ p $<0.001)$; $\$$ indicates statistically significant differences between the metformin and glibenclamide treated groups, as determined by the Kruskal-Wallis test followed by a Dunn's multiple comparisons post-hoc test.

the impact of these trace elements on the pathogenesis of T2DM as well as the effect of glycemic status on their levels (Khan et al., 2015, Viktorinova et al., 2009). However, Basaki et al. (2012) showed that diabetic patients have a lower $\mathrm{Cu}$ level compared to the control, whereas Terrés-Martos et al. (1998) exhibited no significant differences in the $\mathrm{Cu}$ level between diabetic patients and the control. Higher levels of $\mathrm{Cu}$ in type 2 diabetic patients are possibly associated with hyperglycemia due to disruption of the Cu-binding 
proteins (Talaei et al., 2011), whereas lower levels of $\mathrm{Zn}$ and $\mathrm{Mg}$ may be attributed to hyperglycemia induced disturbances in the factors that maintain their balance, such as intestinal absorption and urinary excretion (Mishra and Mishra, 2017, Yerlikaya et al., 2013).

The present study showed that patients treated with metformin have a significantly lower serum $\mathrm{Cu}$ level compared with glibenclamide and newly diagnosed diabetic patients, while treatment with glibenclamide had no significant effect. Our results are inconsistent with those of Dosa et al. (2011), who reported a non-significant effect of metformin on the plasma concentration of $\mathrm{Cu}$ in type 2 diabetic patients. In contrast, our data is in line with Zargar et al. (1998), who revealed that glibenclamide does not affect plasma copper levels. In the current study, the difference between the effects of the treated groups on serum $\mathrm{Cu}$ may be related to glycaemic control. Metformin treated patients showed a significantly lower FSG level compared to the newly diagnosed group. This could be, in part, explained by the increasing affinity of $\mathrm{Cu}$ for ceruloplasmin due to decreased glycation by metformin (Roxborough et al., 1995, Sarkar et al., 2010). However, the results of our study showed no difference between the metformin and glibenclamide treated groups in terms of their effects on FSG. Another reason for a decrease in serum $\mathrm{Cu}$ may be due to the ability of metformin to abstract $\mathrm{Cu}$ ions from the biological system, resulting in complex formation (Quan et al., 2015).

With respect to $\mathrm{Zn}$, both the metformin and glibenclamide treated groups showed significantly higher levels compared to the newly diagnosed group. Previous studies about the effect of metformin on the serum $\mathrm{Zn}$ level in type 2 diabetic patients have shown conflicting and even contrary results. Dosa et al. (2011) showed that metformin administration does not lead to significant changes in the plasma concentration of $\mathrm{Zn}$ in patients with non-insulin-dependent diabetes mellitus. In contrast, Naik et al. (2019) revealed that metformin alone or in combination with glimiperide causes a significant decrease in serum zinc levels in type 2 diabetic patients. Regarding glibenclamide, our findings of higher serum concentration of $\mathrm{Zn}$ compared to the untreated group is in line with those obtained in a previous study on streptozotocin-induced diabetic rats (Shawky et al., 2018). In the present study, the increment in the serum $\mathrm{Zn}$ level in the treated groups may be related to the improvement in the glycaemic parameters, including FSG. A significant decrease in FSG might result in a decrease in $\mathrm{Zn}$ urinary loss and an increase in its active transport to tubular cells (Praveeena S., 2013). However, the glibenclamide treated group, unlike its metformin counterpart, did not show significant low FSG levels compared to the newly diagnosed group. In contrast, patients treated with glibenclamide showed comparable insulin levels to the control. $\mathrm{Zn}$ is important for synthesis and release of insulin, and its shortage appears to affect insulin release (Lobo et al., 2010). Therefore, the ability of glibenclamide to increase $\mathrm{Zn}$ levels could be related to its role in stimulation of insulin release from the pancreatic $\beta$-cells.

In the current study, the use of glibenclamide resulted in an increase in serum magnesium to a level comparable to the control and significantly higher than the newly diagnosed group. By contrast, metformin did not significantly change serum $\mathrm{Mg}$ levels, leading to significantly lower levels than the control. Our results are in accordance with the findings of previous studies (Chakraborty et al., 2011, Wahlen et al., 2017). Even though the glibenclamide treated group in the present study had worse glycaemic control, they showed better serum $\mathrm{Mg}$ levels than the patients treated with metformin. This outcome can be attributed to the ability of glibenclamide to increase insulin levels. This is in agreement with previous studies showing that insulin has an essential role in the renal reabsorption of $\mathrm{Mg}$ (Kurstjens et al., 2017) by stimulating the renal Mg channel TRPM6 (Nair et al., 2012). In contrast to our findings, Peters et al. (2013) reported lower serum magnesium concentrations in patients receiving metformin monotherapy or in combination with a sulfonylurea compared to those on diet alone.

It is necessary to emphasise that this study has several limitations due to restricted funds. Glycated haemoglobin (HbAlc) and intracellular magnesium were not measured. Moreover, collection of samples occurred at a single point, and no follow-up data is available.

\section{Conclusion}

The present study demonstrated an elevation in serum $\mathrm{Cu}$ and a reduction in serum $\mathrm{Zn}$ and $\mathrm{Mg}$ in T2DM. It also showed that metformin treatment is associated with decreased serum $\mathrm{Cu}$ and increased serum $\mathrm{Zn}$. In contrast, glibenclamide treated patients revealed improvement in serum levels of $\mathrm{Mg}$ and $\mathrm{Zn}$.

\section{Acknowledgments}

The authors thankfully acknowledge the University of Mosul and the College of Pharmacy for their continuous support and encouragement to all researchers.

\section{References}

Basaki M, Saeb M, Nazifi S, Shamsaei HA (2012) Zinc, copper, iron, and chromium concentrations in young patients with type 2 diabetes mellitus. Biological Trace Element Research 148: 161-164. https:// doi.org/10.1007/s12011-012-9360-6
Chakraborty A, Chowdhury S, Bhattacharyya M (2011) Effect of metformin on oxidative stress, nitrosative stress and inflammatory biomarkers in type 2 diabetes patients. Diabetes Research and Clinical Practice 93: 56-62. https://doi.org/10.1016/j.diabres.2010.11.030 
DiSilvestro RA (2000) Zinc in relation to diabetes and oxidative disease. Journal of Nutrition 130: 1509S-1511S. https://doi.org/10.1093/ jn/130.5.1509S

Dosa MD, Hangan LT, Crauciuc E, Gales C, Nechifor M (2011) Influence of therapy with metformin on the concentration of certain divalent cations in patients with non-insulin-dependent diabetes mellitus. Biological Trace Element Research 142: 36-46. https://doi. org/10.1007/s12011-010-8751-9

Huerta MG, Roemmich JN, Kington ML, Bovbjerg VE, Weltman AL, Holmes VF, Patrie JT, Rogol AD , Nadler JL (2005) Magnesium deficiency is associated with insulin resistance in obese children. Diabetes Care 28: 1175-1181. https://doi.org/10.2337/diacare.28.5.1175

Khan FA, Al Jameil N, Arjumand S, Khan MF, Tabassum H, Alenzi N, Hijazy S, Alenzi S, Subaie S , Fatima S (2015) Comparative Study of Serum Copper, Iron, Magnesium, and Zinc in Type 2 Diabetes-Associated Proteinuria. Biological Trace Element Research 168: 321-329. https://doi.org/10.1007/s12011-015-0379-3

Kurstjens S, de Baaij JH, Bouras H, Bindels RJ, Tack CJ , Hoenderop JG (2017) Determinants of hypomagnesemia in patients with type 2 diabetes mellitus. European Journal of Endocrinology of the European Federation of Endocrine Societies 176: 11-19. https://doi. org/10.1530/EJE-16-0517

Lobo JC, Torres JP, Fouque D, Mafra D (2010) Zinc deficiency in chronic kidney disease: is there a relationship with adipose tissue and atherosclerosis? Biological Trace Element Research 135: 16-21. https:// doi.org/10.1007/s12011-009-8504-9

Mishra S , Mishra BB (2017) Study of Lipid Peroxidation, Nitric Oxide End Product, and Trace Element Status in Type 2 Diabetes Mellitus with and without Complications. Int J Appl Basic Med Res 7: 88-93. https://doi.org/10.4103/2229-516X.205813

Naik SK, Ramanand SJ , Ramanand JB (2019) A Medley Correlation of Serum Zinc with Glycemic Parameters in T2DM Patients. Indian Journal of Endocrinology and Metabolism 23: 188-192. https://doi. org/10.4103/ijem.IJEM_7_19

Nair AV, Hocher B, Verkaart S, van Zeeland F, Pfab T, Slowinski T, Chen YP, Schlingmann KP, Schaller A, Gallati S, Bindels RJ, Konrad M , Hoenderop JG (2012) Loss of insulin-induced activation of TRPM6 magnesium channels results in impaired glucose tolerance during pregnancy. Proceedings of the National Academy of Sciences of the United States of America 109: 11324-11329. https://doi.org/10.1073/ pnas.1113811109

Peters KE, Chubb SA, Davis WA, Davis TM (2013) The relationship between hypomagnesemia, metformin therapy and cardiovascular disease complicating type 2 diabetes: the Fremantle Diabetes Study. PloS One 8: e74355. https://doi.org/10.1371/journal.pone.0074355

Praveeena S. SP, K. Sameera (2013) Trace Elements in Diabetes Mellitus. 7: 1863-1865. https://doi.org/10.7860/jcdr/2013/.3335

Quan X, Uddin R, Heiskanen A, Parmvi M, Nilson K, Donolato M, Hansen MF, Rena G, Boisen A (2015) The copper binding properties of
metformin--QCM-D, XPS and nanobead agglomeration. Chemical Communications (Cambridge, England) 51: 17313-17316. https:// doi.org/10.1039/c5cc04321b

Quraishi I, Collins S, Pestaner JP, Harris T, Bagasra O (2005) Role of zinc and zinc transporters in the molecular pathogenesis of diabetes mellitus. Medical Hypotheses 65: 887-892. https://doi.org/10.1016/j. mehy.2005.02.047

Roxborough HE, Millar CA, McEneny J , Young IS (1995) Carbamylation inhibits the ferroxidase activity of caeruloplasmin. Biochemical and Biophysical Research Communications 214: 1073-1078. https:// doi.org/10.1006/bbrc.1995.2395

Sarkar A, Dash S, Barik BK, Muttigi MS, Kedage V, Shetty JK, Prakash M (2010) Copper and ceruloplasmin levels in relation to total thiols and GST in type 2 diabetes mellitus patients. Indian Journal of Clinical Biochemistry 25: 74-76. https://doi.org/10.1007/s12291010-0015-0

Shawky S, Abdel-Aziz SA, Amer HA, Hegazy I, Hussein MA (2018) Comparison of Biochemical effects of glibenclamide and some trace elements on experimental diabetic rats. Sci J of Oct 6 Univ 4: 1-7. https://doi.org/10.21608/sjou.2018.30310

Soinio M, Marniemi J, Laakso M, Pyorala K, Lehto S, Ronnemaa T (2007) Serum zinc level and coronary heart disease events in patients with type 2 diabetes. Diabetes Care 30: 523-528. https://doi. org/10.2337/dc06-1682

Talaei A, Jabari S, Bigdeli MH, Farahani H, Siavash M (2011) Correlation between microalbuminuria and urinary copper in type two diabetic patients. Indian Journal of Endocrinology and Metabolism 15: 316-319. https://doi.org/10.4103/2230-8210.85586

Terrés-Martos C, Navarro-Alarcón M, Martín-Lagos F, López-Ga De La Serrana H, Pérez-Valero V , López-Mart ínez MC (1998) Serum Zinc and Copper Concentrations and $\mathrm{Cu} / \mathrm{Zn}$ ratios in Patients with Hepatopathies or Diabetes. Journal of Trace Elements in Medicine and Biology 12: 44-49. https://doi.org/10.1016/s0946-672x(98)80020-5

Viktorinova A, Toserova E, Krizko M , Durackova Z (2009) Altered metabolism of copper, zinc, and magnesium is associated with increased levels of glycated hemoglobin in patients with diabetes mellitus. Metabolism: Clinical and Experimental 58: 1477-1482. https://doi. org/10.1016/j.metabol.2009.04.035

Wahlen A, Haenni A, Johansson HE (2017) Do we need to measure vitamin B12 and magnesium in morbidly obese patients with type 2 diabetes mellitus? Diabetes, Metabolic Syndrome and Obesity 10: 151-154. https://doi.org/10.2147/DMSO.S131340

Yerlikaya FH, Toker A , Aribas A (2013) Serum trace elements in obese women with or without diabetes. Indian Journal of Medical Research 137: 339-345. https://www.ncbi.nlm.nih.gov/pubmed/23563378

Zargar AH, Shah NA, Masoodi SR, Laway BA, Dar FA, Khan AR, Sofi FA, Wani AI (1998) Copper, zinc, and magnesium levels in non-insulin dependent diabetes mellitus. Postgraduate Medical Journal 74: 665-668. https://doi.org/10.1136/pgmj.74.877.665 